\title{
20. VOLCANIC ASH FROM DSDP SITE 178, GULF OF ALASKA
}

\author{
Richard M. Pratt, NOAA, Rockville, Maryland; Kenneth F. Scheidegger and LaVerne D. Kulm, \\ Oregon State University, Corvallis, Oregon
}

A large number of well-defined ash layers occur in the Middle Miocene to Holocene sediments cored at Site 178. Fifty-three samples of silt and sand were selected for a special study of the stratigraphic distribution of volcanic ash and its composition. A smear slide mounted in Cadex was made of all samples and extra ash was retained for measurement of refractive indices with oils (Table 1). In addition, several samples were sized by seiving and were run through a Frantz magnetic separator. Of the fifty-three samples examined for ash, fifteen had over 90 per cent ash (visual estimate) and twenty-six had more than 50 per cent ash. Two varieties of ash were found: a light variety that forms well-sorted, distinct layers and a dark brown variety that is usually found in trace amounts throughout the sediment column.

The light ashes consist almost totally of clear, isotropic glass shards although several of the samples contain numerous crystals of feldspar and quartz. The vertical distribution of the ash in the sediment column and the average refractive indices are presented in Table 1. In general, the light ash is fairly well divided into the medium to coarse silt range. Individual shards are usually angular and about one-third of the samples contained shards that show lineations, small bubbles, or other evidence of flowage. Some shards, which are particularly large and thin, are nearly triangular in shape and are probably remnants of bubble walls. The light ash from Core 1 through Core 39 has an index of refraction of 1.502 to 1.512 . Chemical analyses of selected light ash samples in Cores 1, 21, 28, 34, and 39 verify that all light ashes observed at Site 178 form a chemically uniform population (see Table 2). Using calculated CIPW normative mineralogy in place of modal mineralogy in the classification scheme of Johannsen (1931), one finds that all of the light ashes listed in Table 2 are rhyodacites.

The only large recorded volcanic eruption to distribute ash over Site 178 was the 1912 eruption of Mount Katmai (Nayudu, 1964). Although ash from this eruption was looked for in the uppermost sediment at Site 178, it was not found. A sample of Katmai ash from Kodiak Island was studied as part of this investigation (see Table 2). The average index of refraction of our Katmai ash sample (1.484) agrees well with the value of $1.485 \pm .002$ reported by Nayudu (1964). Interestingly, our data suggest that Katmai ash has a distinctly lower index of refraction (1.484) and probably a higher silica content than any of the ash samples from Site 178. Just why the only known historic eruption to deposit ash in the area is different remains a problem. It hardly seems reasonable to accept the one historic event as a major change in 15 million years of ash chronology, but on the other hand, the Aleutian system may just now be reaching a state of maturity that supports the production of highly siliceous magma.

The dark ash ranges from olive brown to green and generally has an index of refraction of around 1.56 or greater. It characteristically occurs as a rare component with light ash or detrital silt. Generally, dark ash shows mottled extinction, lacks flow striations or bubbles, and is usually more rounded than those of light ash. Six samples, including one with 85 per cent ash, fell within the 1.55 to 1.56 refractive index range. The first dark ash found in the stratigraphic section at Site 178 composes 2 to 3 per cent of the sample and may correspond to the dark ash or "middle" ash described by Nayudu (1964). Site 178 is located within the northeast Pacific brown ash province described by Hays and Ninkovich (1970). The fact that dark ash is less abundant than light ash at Site 178 is probably a consequence of the greater explosiveness associated with eruptions of highly siliceous magmas.

The geological significance of the ash deposits found at Site 178 is that light ash of rhyodacitic composition and Middle Miocene age is found as deep as Core 39 at about 400 meters. This may not be a maximum depth because there was no recovery from the next three cores and recovery was very poor for the rest of the hole. Our studies indicate that island arc volcanism of the Alaska Peninsula has been contributing highly siliceous ash for a much longer period of time than has been suggested by Hays and Ninkovich (1970). In addition, the abundance of ash layers in Pliocene and younger sediments may be a consequence of the uplift and volcanism associated with the development of the present Alaska Peninsula in upper Pliocene time (Burk, 1965).

\section{ACKNOWLEDGMENTS}

We thank John B. Corliss for his critical review of this manuscript.

\section{REFERENCES}

Berggren, W. A., 1972. A Cenozoic time-scale - some implications for regional geology and paleobiogeography. Lethaia 5, 195.

Burk, C. A., 1965. Geology of the Alaska Peninsula Island arc and continental margin. Geol. Soc. Amer. Mem. 99, Part 1.

Hays, J. C. and Ninkovich, D., 1970. North Pacific deep-sea ash chronology and the age of present Aleutian underthrusting. Geol. Soc. Am. Mem. 126. 263.

Johannsen, A., 1931. A descriptive petrography of the igneous rocks. Vol. 1. Chicago (The University of Chicago Press). 267 p.

Nayudu, Y. R., 1964. Volcanic ash deposits in the Gulf of Alaska and problems of correlation of deep-sea ash deposits. Marine Geology. 1, 194. 
TABLE 1

Distribution and Refractive Index of Ash from Site 178

\begin{tabular}{|c|c|c|c|c|c|c|}
\hline Core & Section & $\begin{array}{c}\text { Interval } \\
\text { (cm from } \\
\text { top) }\end{array}$ & $\begin{array}{l}\text { Depth } \\
(\mathrm{m})\end{array}$ & $\begin{array}{l}\text { Bed } \\
\text { Thickness } \\
(\mathrm{cm})\end{array}$ & Petrographic Description & $\begin{array}{l}\text { Refractive } \\
\text { Index }^{\mathrm{a}}\end{array}$ \\
\hline 1 & 1 & $111-112$ & 1 & 1 & $2-3 \%$ olive brown ash & $<1.560$ \\
\hline 1 & 3 & $89-90$ & 4 & 4 & $100 \%$ light ash & 1.508 \\
\hline 1 & 4 & $11-12$ & 4 & 2 & $99 \%$ light ash & 1.508 \\
\hline 3 & 3 & $19-20$ & 18 & 2 & $95 \%$ light ash (crystals present) & $1.500-1.510$ \\
\hline 3 & 3 & $143-144$ & 19 & 1 & $\begin{array}{l}50 \% \text { light ash (large angular shards, } \\
\text { quartz crystals abundant) }\end{array}$ & 1.512 \\
\hline 3 & 4 & $123-134$ & 20 & 19 & $85 \%$ light ash & $1.508-1.510$ \\
\hline 5 & 3 & $143-144$ & 38 & & Rare ash & $1.610-1.620$ \\
\hline 5 & 4 & $48-50$ & 39 & 2 & $\begin{array}{l}70 \% \text { light ash (well-sorted, crystals } \\
\text { abundant) }\end{array}$ & 1.500 \\
\hline 6 & 3 & $144-150$ & 46 & & Rare light ash & \\
\hline 6 & 4 & $82-84$ & 47 & 2 & $100 \%$ light ash (fine-grained) & 1.512 \\
\hline 8 & 1 & $64-65$ & 60 & & $95 \%$ light ash & 1.510 \\
\hline 9 & 4 & $15-18$ & 73 & 3 & $5 \%$ dark ash & \\
\hline 10 & 2 & $105-109$ & 80 & 4 & $100 \%$ light ash (crystals present) & 1.512 \\
\hline 12 & 3 & $45-46$ & 99 & 1 & $50 \%$ light ash (crystals present) & 1.500 \\
\hline 12 & 3 & $66-69$ & 99 & 3 & $1-2 \%$ brown green ash & \\
\hline 17 & 4 & $98-96$ & 146 & 7 & $2 \%$ light ash & 1.512 \\
\hline 18 & 2 & $95-96$ & 152 & 45 & $100 \%$ light brown ash & 1.522 \\
\hline 18 & 2 & $116-117$ & 152 & 45 & $85 \%$ brown ash & $1.545-1.552$ \\
\hline 18 & 3 & $44-45$ & 153 & 1 & $\begin{array}{l}80 \% \text { light ash (trace dark ash is } \\
\text { present) }\end{array}$ & $1.510-1.515$ \\
\hline 21 & 2 & $95-98$ & 179 & 4 & $\begin{array}{l}90 \% \text { light brown ash (crystals } \\
\text { present, shards striated) }\end{array}$ & 1.538 \\
\hline 24 & 2 & $33-34$ & 205 & & $\begin{array}{l}100 \% \text { light ash (some shards are } \\
\text { striated) }\end{array}$ & 1.502 \\
\hline 26 & 3 & $79-82$ & 223 & 3 & $50 \%$ light ash, $30 \%$ dark ash & \\
\hline 28 & 2 & $136-137$ & 240 & 5 & $\begin{array}{l}94 \% \text { light ash (clear, well-sorted, } \\
\text { large shards) }\end{array}$ & 1.512 \\
\hline 28 & 3 & $6-7$ & 242 & 1 & $70 \%$ light ash & 1.515 \\
\hline 28 & 5 & $122-123$ & 245 & 2 & $\begin{array}{l}90 \% \text { light ash (well-sorted and } \\
\text { uniform) }\end{array}$ & 1.512 \\
\hline 29 & 5 & $97-98$ & 255 & 1 & $\begin{array}{l}90 \% \text { light brown ash (shards striated } \\
\text { and flow structures are present) }\end{array}$ & 1.530 \\
\hline 32 & 2 & $13-24$ & 307 & 11 & Trace brown ash & 1.560 \\
\hline 33 & 1 & $94-95$ & 316 & 1 & $50 \%$ light ash & 1.512 \\
\hline 33 & 1 & $125-128$ & 316 & 3 & Trace light ash & \\
\hline 34 & 6 & $105-110$ & 333 & 5 & $100 \%$ light ash (graded) & 1.510 \\
\hline 36 & 2 & $111-112$ & & 1 & Ash-bearing diatomite & \\
\hline 37 & 3 & $60-65$ & 356 & 5 & $50 \%$ light ash (graded) & 1.502 \\
\hline 39 & 5 & $114-115$ & 396 & 19 & $20 \%$ light ash (graded; crystals present) & 1.510 \\
\hline 39 & 5 & $119-120$ & 396 & 19 & $50 \%$ light ash (graded) & 1.502 \\
\hline 44 & 4 & $70-80$ & 461 & 10 & Light ash (graded; crystals numerous) & 1.505 \\
\hline 47 & 2 & $110-115$ & 507 & 5 & $2 \%$ dark brown ash (shards angular) & $<1.560$ \\
\hline 51 & 1 & $124-125$ & 658 & 1 & $\begin{array}{l}10 \% \text { brown ash (shards are angular, } \\
\text { show mottled extinction and may } \\
\text { be detrital) }\end{array}$ & $<1.560$ \\
\hline
\end{tabular}

${ }^{\mathrm{a}}$ Single refractive index values are averages of several measurements.

TABLE 2

Chemical Analyses of Volcanic Ash Layers From Site 178

\begin{tabular}{|c|c|c|c|c|c|c|}
\hline & $\begin{array}{c}\text { Katmai } \\
\text { Ash }\end{array}$ & $\begin{array}{c}\text { Interval } \\
1-3(89-90)\end{array}$ & $\begin{array}{c}\text { Interval } \\
21-2(95-99)\end{array}$ & $\begin{array}{c}\text { Interval } \\
28-2(136-137) \\
\end{array}$ & $\begin{array}{c}\text { Interval } \\
34-6(105-110) \\
\end{array}$ & $\begin{array}{c}\text { Interval } \\
39-5(119-120) \\
\end{array}$ \\
\hline $\mathrm{SiO}$ & 75.91 & 71.47 & 65.13 & 67.50 & 70.53 & 71.14 \\
\hline TiO & 0.18 & 0.20 & 0.59 & 0.19 & 0.20 & 0.28 \\
\hline $\mathrm{Al}_{2} \mathrm{O}_{3}$ & 12.64 & 13.93 & 15.45 & 14.90 & 13.32 & 13.65 \\
\hline $\begin{array}{l}\mathrm{FeO} \text { (total } \\
\mathrm{Fe} \text { ) }\end{array}$ & 1.09 & 1.91 & 4.75 & 2.18 & 1.72 & 1.68 \\
\hline $\mathrm{MgO}$ & 0.12 & 0.23 & 0.97 & 0.45 & 0.27 & 0.32 \\
\hline $\mathrm{CaO}$ & 0.96 & 1.74 & 3.11 & 0.92 & 1.17 & 1.49 \\
\hline $\mathrm{Na}_{2} \mathrm{O}$ & 4.32 & 4.38 & 4.57 & 4.12 & 3.91 & 4.05 \\
\hline $\mathrm{K}_{2} \mathrm{O}$ & 2.80 & 3.52 & 2.21 & 3.14 & 4.20 & 3.22 \\
\hline $\begin{array}{l}\text { Average } \\
\text { Refractive } \\
\text { Index }\end{array}$ & 1.484 & 1.508 & 1.538 & 1.512 & 1.510 & 1.502 \\
\hline
\end{tabular}

